\title{
Job Satisfaction of Teacher Educators in Different Types of B.Ed. Colleges in West Bengal
}

\author{
Pranab Barman ${ }^{1} \&$ Dr. Dibyendu Bhattacharyya ${ }^{2}$ \\ ${ }^{1}$ (Assistant Professor; Dept. of Education; Sidho-Kanho-Birsha University, Purulia, West Bengal, India) \\ ${ }_{2}^{2}$ (Professor; Dept. of Education; University of Kalyani, Kalyani, Nadia, West Bengal, India)
}

\begin{abstract}
Job Satisfaction of employees of any organization is a key factor in the overall progress of that organization. That's why many researchers has considered Job Satisfaction as one of the most important influencing factors which can motivate employees to perform their job positively and increase the level of performance as well as their productivity. But it is not very easy to ensure Job Satisfaction of employees because it depends on so many factors. Through the present study an attempt has been made by the investigators to assess the level of Job Satisfaction of Teacher Educators working in different types of B.Ed. colleges in West Bengal in relation to some personal and socio-demographic variables. The investigators have used Descriptive Survey method for the present study. The sample consists of 405 Teacher Educators who are working in different Government Aided and Private or Self-Financed B.Ed colleges in West Bengal. The stratified random sampling technique has been used for the selection of sample in the present study. The investigators have developed a self made questionnaire followed by Likert's five point scale i.e. Strongly Agree (S.A), Agree (A), Neutral (N), Disagree (D) and Strongly Disagree (S.D). For the analysis of data Mean, S.D., t-test, ANOVA and graph have been used by the investigators in the present study. The results of the study explore that Teacher Educators working in different Govt. Aided and Private B.Ed. colleges in West Bengal are satisfied with their job overall. They are satisfied with all the dimensions or aspects of Job Satisfaction except only one dimension i.e. salary \& compensation. Out of 13 personal and socio-demographic variables only two variables viz., (i) Location of College and (ii) Occupation of Spouse have a statistically significant influence on overall Job Satisfaction of Teacher Educators and Gender, Marital Status, Educational Qualification, Teacher's Locality, Type of Family, Type of Management of the College, Age, Teaching Experience, Size of the Family, and Monthly Income have no statistically significant influence on overall Job Satisfaction of Teacher Educators working in different types of B.Ed. colleges in West Bengal.
\end{abstract}

Key Words:- Job Satisfaction, Teacher Educators, B.Ed. College

\section{INTRODUCTION}

Teaching is one of the best and noble professions and the teacher is a prominent personality in this world. Teachers are a knowledge ambassador and arguably the most important group of professionals for nurturing the young minds. All the resource persons or members of other professions are made by the teachers. So teacher has a significant role in making the students life bright and productive. And Teacher Educators play a vital role in case of making teachers who are engaged directly to teach the students of various levels of education. Hence, a great emphasis should be given on the matter of teacher educators. The quality of teaching depends upon active, dedicated and satisfied teachers. The teachers who are satisfied with their job can perform their responsibilities with more concentration and devotion. It is an established fact that a satisfied teacher puts his/her best efforts to make teaching more effective. Job Satisfaction positively influences the teachers' performance, students' achievement, organizational commitment and as well as work motivation. Job Satisfaction is a source of motivation that sustains effort in performing tasks required of good teachers (Watson et al., 1991). So, Shanthapparaj \& Solucis (2005) stated that Job Satisfaction is good not only for employees but employers too. It increases productivity and decreases staff turnover within an organization or institution. It definitely promotes happiness, success and efficiency in one's professional activity and also helps in developing a happy and congenial working atmosphere in the workplace. But Job dissatisfaction leads to reduce the level of performance of an employee (Bretz \& Thomas, 1992). Not only this, but also it increases the rate of turnover and turnover intentions or tendencies (Motowidlo, 1983) and also leads to absenteeism (Weiner, 1980).

That's why it is very important to prevent workers or employees from feeling of disappointed and maximize their efficiency and performance by identifying and regulating the factors that affect Job Satisfaction (Eryaman \& Sonmezer, 2008). 


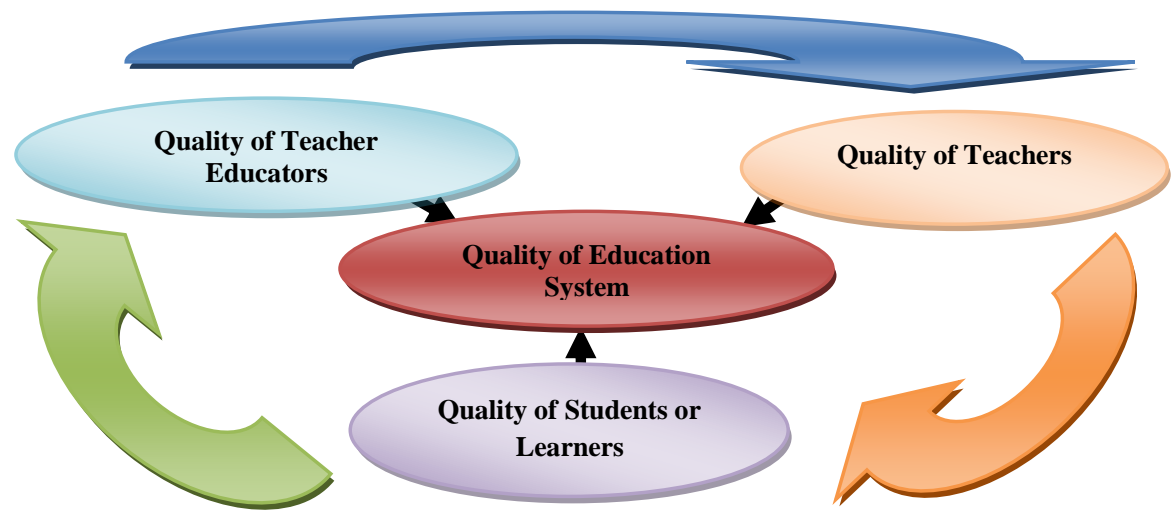

Figure No-1: Shows the Interdependency among the Teacher Educators, Teachers and Students in making Quality Education System

\section{Job Satisfaction: Meaning}

Job Satisfaction is a very important motivation factor which can play a vital role not only in motivating the teachers in classroom performance but also in entire development of an educational institution or organization. Generally, it is found that those teachers are happier with their profession, can perform better than others who are not satisfied with their profession. As Sargent and Hannum (2005) stated, highly effective and motivated teachers are those types of teachers who acquire Job Satisfaction. According to Ingersoll (2001) Job Satisfaction leads the employees to perform better and be motivated in what they do. Good performance and putting more effort are the key factors to achieve organizational goals. Vice versa, those employees who are not happy with their job make less effort and their performance level is not good. Woods and Weasmer (2002) suggested that when teachers are satisfied, the rate of attrition is reduced, collegiality is enhanced, and job performance improves.

\section{Affecting Factors of Job Satisfaction:}

Job Satisfaction or dissatisfaction of a teacher or an employee is influenced by a number of factors. Generally most of the time, Job Satisfaction or dissatisfaction of an employee is influenced by pay, promotion, benefits, supervisor, co-workers, working conditions, communication, security or safety, productivity, and the work itself. Each of these factors figures into an individual's Job Satisfaction differently.

According to Herzberg (1959), Job Satisfaction or dissatisfaction of an employee depends on two major important factors or elements. These are:

i. Intrinsic Factors or Elements: These factors are related to job such as achievement, recognition for achievement, the work itself, responsibilities, and growth or advancement. He describes these factors as "Motivation factors".

ii. Extrinsic Factors or Elements: This is related to institution such as working conditions, salary, supervision, company or institutional policy and administration, interpersonal relationships, status, and security. $\mathrm{He}$ considered these factors as "hygiene factors" or "context" factors.

Harrel (1968) in his famous book 'Industrial Psychology' stated that Job Satisfaction of an employee is influenced by many interrelated factors. He divided them into three major categories of factors. They are:

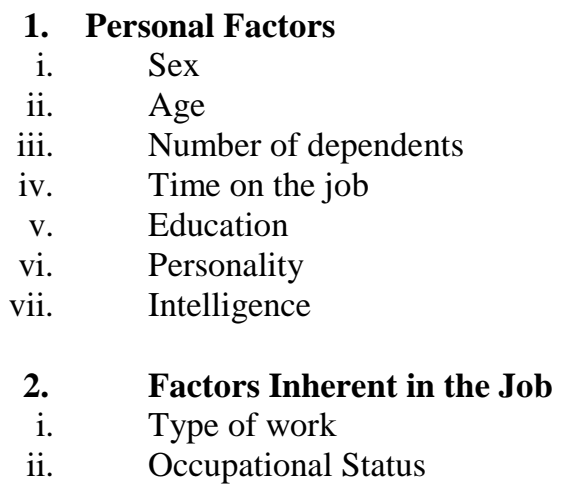




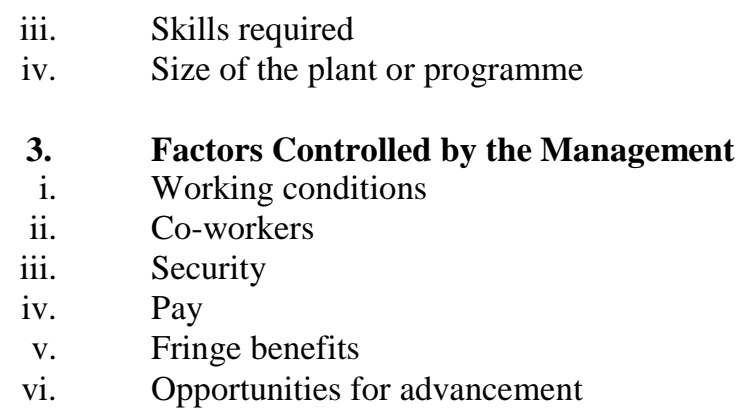

Spectors (1985) defined Job Satisfaction as a cluster of evaluative feelings about the job. He identified 9 facets of Job Satisfaction. These are as follows:

i. Pay: It means that amount and fairness or equity of salary.

ii. Promotion: It refers to opportunities and fairness of promotion.

iii. Supervision: It means that fairness and competence at managerial tasks by ones supervisor.

iv. Benefits: It is related to insurance, vacation, and other fringe benefits.

v. Contingent Procedures: It is related to sense of respect, recognition and appreciation.

vi. Operating Procedure: It denotes policies, procedures, rules, perceived red tape.

vii. Coworkers: It refers to perceived competence and pleasantness of one's colleagues.

viii. $\quad$ Nature of Work: It is related to enjoyment of the actual tasks themselves.

ix. Communication: It refers to sharing information within the organization (verbally or in written).

Kim and Loadman (1994) listed seven predictors or factors of Job Satisfaction. These are as follows:

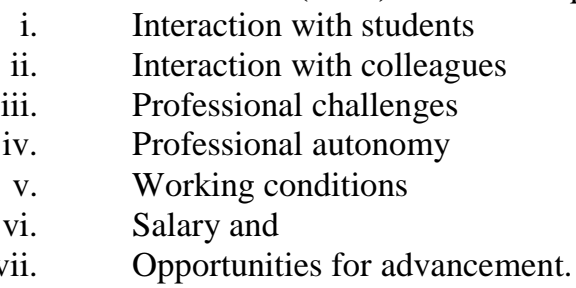

Afsar Khan (1995) opined that there are several factors that are responsible in creating Job Satisfaction or dissatisfaction among an employee. He has divided the factors into four major areas or categories. These are as follows:

\section{A. Job Characteristics:}

Herzberg (1968) in his two factor theory has categorized job characteristics into two sub categories, i.e (a) job content related factors or intrinsic factors and (b) job context related factors or extrinsic factors.

(a) Intrinsic Factors: Job content related factors or intrinsic factors are related to the nature of a job itself. These factors include the following aspects of a job:

i. $\quad$ The challenge and interest of the work

ii. $\quad$ Perception of the worth of the work

iii. Control/freedom of the job

iv. Participation in decision making or amount of responsibility and decision making power accompanying the job

(b) Extrinsic Factors: Job context related factors or extrinsic factors are related to the context of a job where a person or employee has to perform his/her work or job. These factors include the following aspects of a job:

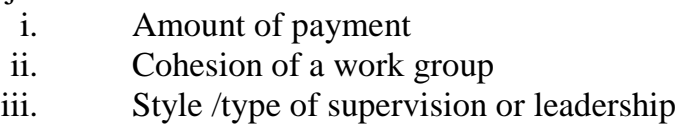

\section{B. Individual Characteristics:}

These are also known as personal characteristics. The most important individual or personal characteristics that are responsible in determining the Job Satisfaction or dissatisfaction of an employee are:

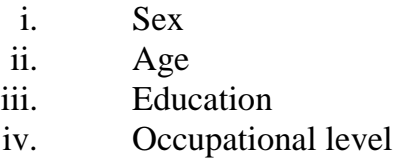




\section{Organizational Characteristics:}

These are other important influencing factors in determining the Job Satisfaction or dissatisfaction of an employee. Actually these characteristics of Job Satisfaction or dissatisfaction are associated with the variables of organizational structure. The most important of these are:

i. Infrastructure of the organization

ii. Service benefits

iii. Recreational facilities

iv. Placement and promotion

\section{Work Situation Characteristics:}

The work situation related characteristics or factors are one of the most influencing factors in determining the Job Satisfaction or dissatisfaction of an employee. The important work situation related characteristics or factors are:

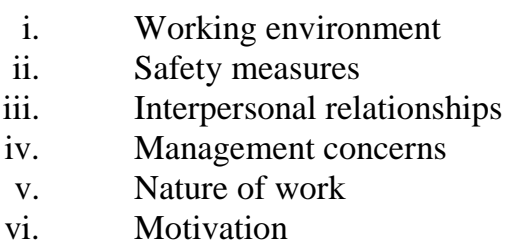

Prasad (2004) opined that there are many factors or determinants which are responsible in determining the Job Satisfaction or dissatisfaction of an employee. He has classified them into three broad categories or dimensions:

A. Individual Factors: Individuals have certain expectations from their jobs. If these expectations are met from the job, they feel satisfied. These expectations are based on the following aspects:

i. Level of Education

ii. Age

iii. $\quad$ Other factors i.e may be social and family life

B. Nature of Job: Nature of job is one of the most influencing factors of Job Satisfaction of an employee. Prasad included two aspects in this dimension:

i. Occupation level

ii. Job content

C. Situational Variables: It is related to organizational context where the management and interaction of individuals take place in the organization. Some of the important situational variables or factors which affect Job Satisfaction of an employee are given as follow.

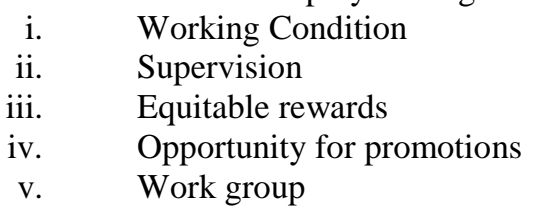

Singh (2010) has stated the factors or determinants of Job Satisfaction reported by the researcher Hodgetts (1991) in his study. These are as follows:

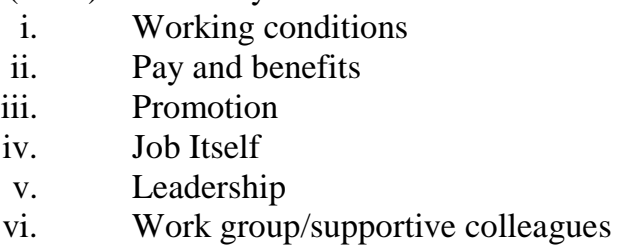

Through the above discussion on the affecting factors of Job Satisfaction, it is clear that there are number of factors or determinants responsible in making Job Satisfaction or dissatisfaction among an employee. Many scholars on the basis of their own perceptions have mentioned a lot of factors or determinants which can influence the level of Job Satisfaction or dissatisfaction of an employee. Few of them reported that intrinsic and extrinsic factors are the responsible factors in case of determining the Job Satisfaction or dissatisfaction among an employee. Few of them stated that Job Satisfaction or dissatisfaction of an employee largely depends on the individual or personal factors, Nature of Job related factors, Institutional factors and work situational factors.

\section{REVIEW OF RELATED LITERATURE}


Sylvester (2010) has conducted a study on "Attitude towards Teaching Profession and Job Satisfaction of Teacher Educators" and revealed that the factors like gender, location of institutes, teaching experience of Teacher Educators have no significant impact on their attitude towards teaching profession as well as level of Job Satisfaction.

Sridevi (2011) has conducted a study on "Job Satisfaction of Teacher Educators of University of Mysore" and revealed that (i) the majority of the Teacher Educators expressed moderate level of Job Satisfaction. (ii) there no significant differences were found in the Job Satisfaction of the Teacher Educators with respect to gender and locale. And (iii) the Teacher Educators working in aided institutions were highly satisfied with their job than the Teacher Educators of unaided and government institutions.

Gangadhar Rao (2012) has conducted a study on "A Comparative Study between Job Satisfaction and Effectiveness in Teaching of In-Service Teacher Trainees". The study revealed that (i) the In-Service M.Ed. Teacher Trainees working at teacher training institutions are not satisfied in their job. (ii) male and female In-Service M.Ed. Teacher Trainees are satisfied in their job and female teachers are comparatively more satisfied than their male counterparts. And (iii) age factor affects Job Satisfaction level of the In-Service M.Ed. Teacher Trainees. It was observed that as age progresses, Job Satisfaction level goes on declining.

Bhayana (2012) has conducted a study on "A Study of Occupational Self Efficacy, Job Satisfaction and Attitude towards Teaching Profession among Teachers Working in Teacher Training Institutions". The study revealed that (i) gender and teaching experience have no significant effect on Job Satisfaction of teachers working in Teacher Training Institutions. But it was observed that more experienced teachers had more Job Satisfaction than the less experienced teachers.

Singh (2012) has conducted a study on "Job-Satisfaction of Teacher-Educators Working in SelfFinance Teacher Educational Institutions". The study revealed that there was no significant difference among the Teacher Educators working in Secondary teacher educational institution regarding their level of Job Satisfaction with respect to Gender, Area and Age.

Srivastava \& Chabra (2012) have conducted a study on "Job Satisfaction among Teacher Educators: Interplay of Gender and Qualification". The study revealed that (i) the Teacher Educators are extremely satisfied with their jobs and not even a single Teacher Educators was found Dissatisfied with the job. (ii) gender factor does not play a significant role in deciding the satisfaction towards ones job. And (iii) qualification has a significant influence on Job Satisfaction of B. Ed. Teacher Educators. It was observed that NET qualified Teacher Educators are significantly more satisfied to their jobs as compared to their non-NET qualified counterparts.

Prajapati and Mohalik (2013) have conducted a study on "Job Satisfaction of Teacher Educators in Relation to Sex, Qualification, Experience and Age at Secondary Level in Bihar”. The study revealed that (i) most of the Teacher Educators (47.5\%) are highly satisfied and 22.5\% Teacher Educators are low satisfied with their job when total sample taken together. And (ii) there was significant difference in Job Satisfaction of Teacher Educators in relation to sex, qualification, experience and age. It means that sex, qualification, experience and age had a significant effect on Job Satisfaction of Teacher Educators.

Chandramma (2013) has conducted a study on "Job Satisfaction and Teaching Effectiveness of Teacher Educators". The study revealed that (i) the Teacher Educators are better satisfied with their job as a whole. (ii) among 13 Socio-Demographic variables, the variables viz., (a) Management, (b) Age, and (c) Marital Status, do have significant influence at or above 0.05 level on the overall Job Satisfaction of Teacher Educators. (iii) Teacher Educators working in Private Management Institutions expressed higher level of Job Satisfaction compared to the Government Institutions. (iv) The Young Teacher Educators possessed higher level of Job Satisfaction than the middle aged and the old aged. Therefore, it is clear that as the age increases the level of Job Satisfaction decreases. And (v) the unmarried Teacher Educators expressed higher level of Job Satisfaction than their married counterparts.

Balwaria (2013) has conducted a study on "A Study of Job Satisfaction of Teacher Educators Associated with Professional Variable". The study revealed that (i) the Job Satisfaction of secondary Teacher Educators working in Gujarat was found to be highly moderate. (ii) there is significant difference in Job Satisfaction of secondary Teacher Educators with respect to their teaching experience. It was observed that the Job Satisfaction of more experienced secondary Teacher Educators is high than that of less experienced secondary Teacher Educators. And (iii) there is no significant difference in Job Satisfaction of secondary Teacher Educators with respect to their educational qualification.

Anees (2013) has conducted a study on "A Comparative Study of Job Satisfaction of Teacher Educators working in Public Funded Institutions in Relation to their Work Motivation". The study revealed that there is no significant difference in Job Satisfaction of male and female Teacher Educators working in public funded institutions. Anees (2013) has conducted another study on "A Comparative Study of Job Satisfaction of Teacher Educators Working in Private and Public Funded Institutions in Relation to their 
Work Motivation And Occupational Aspirations". The study revealed that there is no significant difference in overall Job Satisfaction of Teacher Educators working in private and public funded institutions.

Khan and Verma (2014) have conducted a study on "Job Satisfaction of Teacher Educators of Private B.Ed. Colleges Affiliated to G.G.S.I.P. University, Delhi and M. D. University, Rohtak, Haryana: A Comparative Study". The study revealed that majority of the Teacher Educators working in private B.Ed. colleges had shown low level of Job Satisfaction or they are less satisfied with their job.

Thakur (2014) has conducted a study on “A Comparative Study on Job Satisfaction of Teacher Educators in Relation to Private Teachers' Training Institutions of University of Gour Banga and University of Kalyani”. The study revealed that (i) the level of Job Satisfaction of Teacher Educators of private teachers' training institution was containing $0 \%$ for the level of extremely satisfied as well as very satisfied whereas, $13 \%$ containing moderately satisfied, $86 \%$ comprising not satisfied and $1 \%$ was extremely dissatisfied level of Job Satisfaction. Therefore, it can be said that the key percentages of Teacher Educators had no Job Satisfaction. And (ii) there is no significant difference in the level of Job Satisfaction of male and female Teacher Educators in relation to private teachers' training institutions of University of Gour Banga and University of Kalyani.

Alemi (2014) has conducted a study on “Job Satisfaction among Afghan Teacher Educators”. The study revealed that (i) Afghan Teacher Educators are mostly satisfied from two aspect of Job Satisfaction namely job itself and the relation they share with their colleagues. However, they are dissatisfied with salary aspect and working condition. They are less satisfied from the supervision and chances of promotions. (ii) gender does not make any significant difference on Job Satisfaction level of Afghan Teacher Educators. But male Teacher Educators were slightly more satisfied from all aspects of job than their female counterparts. (ii) the work location is a predictor for satisfaction from supervision and work condition in cities and remote areas. The findings of the study indicate that Teacher Educators from remote areas were less satisfied with the working condition of their organization comparing of those who are teaching in cities. (iii) marital status has a significant influence on Job Satisfaction of Teacher Educators. The findings of this study confirmed that married Teacher Educators were slightly less satisfied in all aspects than their single counterparts. (iv) year of Experience has a significant influence on Job Satisfaction of Teacher Educators. It was found that Teacher Educators who taught for a long time were slightly less satisfied from their all aspects of job than those who were new in this profession. And (v) age is an important factor related to Job Satisfaction of Teacher Educators. The study reveals that the younger Teacher Educators (22-35) were more satisfied in all aspects of Job Satisfaction than their aged counterparts (36-55).

Ghosh and Panda (2014) have conducted a study on "A Comparative Study of Job Satisfaction among Teacher Educators in Different Types of Secondary Teachers' Training Institution in West Bengal”. The study revealed that (i) the level of Job Satisfaction of Teacher Educators working in Govt. and Govt. Aided teacher training institutions are better than the Teacher Educators working in self-financing teacher training institutions. And (ii) there is a significant difference among Teacher Educators of Govt. Aided and SelfFinancing teacher training institutions regarding their Job Satisfaction.

Dhondiram (2014) has conducted a study on "A Study of the Relationship between Job Satisfaction and Teaching Aptitude of Teacher Educators in Colleges of Education". The study revealed that most of the B. Ed. College Teacher Educators have average degree of Job Satisfaction.

Bordhan (2015) has conducted a study on "Job Satisfaction of Teacher Educators in relation to sex, qualification, experience and age at secondary level in Kamrup and Nagaon districts of Assam”. The study revealed that (i) $47.5 \%$ of Teacher Educators are highly satisfied and $22.5 \%$ of Teacher Educators are low satisfied with their job which indicates that $50 \%$ of Teacher Educators are not highly satisfied with their job. (ii) age, gender, qualification and experience have a significant effect on the level of Job Satisfaction of Teacher Educators.

Oladosu Christianah Tinu et al. (2015) have conducted a study on “Gender Influence on Job Satisfaction and Job Commitment among Colleges of Education Lecturers". The study revealed that there is a significant difference in Job Satisfaction of Colleges of Education Lecturers based on gender. The female lecturers of Colleges of Education were comparatively more satisfied with their job than their male counterparts. It means that gender has a significant influence on Job Satisfaction of Lecturers of Colleges of Education.

Therefore, it is needless to say that very few studies have been conducted to study the Job Satisfaction and Teaching Effectiveness of B.Ed. level Teacher Educators especially in the context of West Bengal. Whatever the studies have been conducted by the scholars in this state till now, none of them is comprehensive enough so as to enable one to draw any conclusive result regarding these two aspects of B.Ed. College Teacher Educators. Therefore, it is quite reasonable to say that there is an immense need to conduct more and more similar studies in order to reach and draw a general decision regarding Job Satisfaction and Teaching Effectiveness of Teacher Educators who are working in different types of B.Ed. Colleges in West Bengal. Hence, the present investigator felt a strong need to undertake a study on Job Satisfaction and Teaching 
Effectiveness of B.Ed. College Teacher Educators in the context of West Bengal and actually this is the base to select the present study.

\section{OBJECTIVES OF THE STUDY}

1) To find out the level of Job Satisfaction of Teacher Educators working in different types of B.Ed. colleges in West Bengal.

2) To find out the influence of Gender on Job Satisfaction of Teacher Educators working in different types of B.Ed. colleges in West Bengal.

3) To find out the influence of Marital Status on Job Satisfaction of Teacher Educators working in different types of B.Ed. colleges in West Bengal.

4) To find out the influence of Educational Qualification on Job Satisfaction of Teacher Educators working in different types of B.Ed. colleges in West Bengal.

5) To find out the influence of Teacher's Locality on Job Satisfaction of Teacher Educators working in different types of B.Ed. colleges in West Bengal.

6) To find out the influence of Location of College on Job Satisfaction of Teacher Educators working in different types of B.Ed. colleges in West Bengal.

7) To find out the influence of Type of Family on Job Satisfaction of Teacher Educators working in different types of B.Ed. colleges in West Bengal.

8) To find out the influence of Type of Management of the College/Institution on Job Satisfaction of Teacher Educators working in different types of B.Ed. colleges in West Bengal.

9) To find out the influence of Age on Job Satisfaction of Teacher Educators working in different types of B.Ed. colleges in West Bengal.

10) To find out the influence of Teaching Experience on Job Satisfaction of Teacher Educators working in different types of B.Ed. colleges in West Bengal.

11) To find out the influence of Occupation of Spouse on Job Satisfaction of Teacher Educators working in different types of B.Ed. colleges in West Bengal.

12) To find out the influence of Size of the Family on Job Satisfaction of Teacher Educators working in different types of B.Ed. colleges in West Bengal.

13) To find out the influence of Monthly Income on Job Satisfaction of Teacher Educators working in different types of B.Ed. colleges in West Bengal.

\section{HYPOTHESES OF THE STUDY}

$\boldsymbol{H O}_{1:}$ There would not have high level of Job Satisfaction of Teacher Educators working in different types of B.Ed. colleges in West Bengal.

$\boldsymbol{H O}_{2}$ : There would not have any significant influence of Gender on Job Satisfaction of Teacher Educators working in different types of B.Ed. colleges in West Bengal.

$H_{3}$ : There would not have any significant influence of Marital Status on Job Satisfaction of Teacher Educators working in different types of B.Ed. colleges in West Bengal.

$\boldsymbol{H O}_{4}$ : There would not have any significant influence of Educational Qualification on Job Satisfaction of Teacher Educators working in different types of B.Ed. colleges in West Bengal.

$\boldsymbol{H O}_{5 \text { : }}$ There would not have any significant influence of Teacher's Locality on Job Satisfaction of Teacher Educators working in different types of B.Ed. colleges in West Bengal.

$\boldsymbol{H O}_{6:}$ There would not have any significant influence of Location of College on Job Satisfaction of Teacher Educators working in different types of B.Ed. colleges in West Bengal.

$\boldsymbol{H O}_{7:}$ There would not have any significant influence of Type of Family on Job Satisfaction of Teacher Educators working in different types of B.Ed. colleges in West Bengal.

$\boldsymbol{H O}_{8 \text { : }}$ There would not have any significant influence of Type of Management of the College/Institution on Job Satisfaction of Teacher Educators working in different types of B.Ed. colleges in West Bengal.

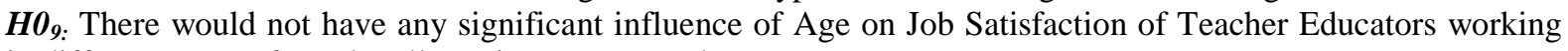
in different types of B.Ed. colleges in West Bengal.

$\boldsymbol{H O}_{10}$ : There would not have any significant influence of Teaching Experience on Job Satisfaction of Teacher Educators working in different types of B.Ed. colleges in West Bengal.

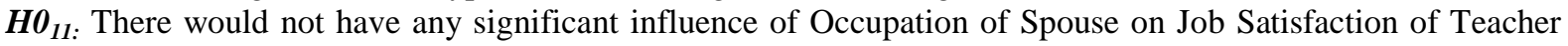
Educators working in different types of B.Ed. colleges in West Bengal.

$\boldsymbol{H O}_{12}$ : There would not have any significant influence of Size of the Family on Job Satisfaction of Teacher Educators working in different types of B.Ed. colleges in West Bengal.

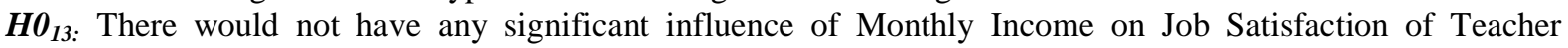
Educators working in different types of B.Ed. colleges in West Bengal. 


\section{OPERATIONAL DEFINITION OF THE TERMS}

\section{Job Satisfaction:}

Job Satisfaction is an attitude of people about their jobs. Operationally, Job Satisfaction in the present study is defined as "the degree to which Teacher Educators have a favourable attitude and contentment with teaching job'. Here in this study, the researcher has used the term 'Job Satisfaction' to mean one kind of favourable psychological feeling or attitude of B.Ed. college Teacher Educators about their job in respect to the dimensions of Working Environment, Availability of Infrastructural Facilities, Colleagues Support, Rapport with Students, Recognition by Others, Leadership Qualities of the Principal/Head, Nature of Job, Individual Autonomy, Academic Planning, Policies of College Authority and Management, Salary \& Compensation, and Opportunities for Development.

\section{Teacher Educators:}

Here in this study, by the term 'Teacher Educators' refers to those teachers who are engaged to teach student-teachers or trainee teachers in different Govt. Aided and Private B.Ed. Colleges in West Bengal. In case of Government Aided B.Ed. colleges only one category of Teacher Educators i.e. Full time Permanent Teachers has been considered as Teacher Educators in the present study. And in case of Private B.Ed. colleges only Full Time Teachers have been considered as Teacher Educators in the present study.

\section{B.Ed. Colleges:}

Here in this study, 'B.Ed. Colleges' refers to those Colleges/Institutions which are engaged to offer/provide B.Ed. degree (Bachelor of Education) to the Student-Teachers or Trainee Teachers having two years full-time recognized B.Ed. programmes in face-to-face mode for preparing teachers for secondary and higher secondary level schools. Here only two types of B.Ed. Colleges are considered for the present study, i.e.

\section{i. Government Aided B.Ed. College:}

Here in this study, Government Aided B.Ed. colleges are those institutions/colleges which are run by Government of West Bengal. These types of B.Ed. colleges are predominantly funded by the Government of West Bengal. Sometimes this type of college is also called as Sponsored B.Ed. college in this state.

\section{ii. Private or Self Financed B.Ed. College:}

Here in this study, Private B.Ed. college means those colleges or institutions which are run by non government organization, charity, or a group of people. The courses being taught in these institutions/colleges are mainly professional courses. One among them is teacher's training programme, approved by the National Council for Teacher Education (NCTE). This type of college is also called as Self Financed B.Ed. college in this state.

\section{METHODOLOGY OF THE STUDY}

Method of the Study: The present study is Descriptive type in nature. Considering the nature of the present problem, the investigator has selected Descriptive type survey method as the most suitable method for conducting the present study. Therefore, naturally the researcher has used the different tools, techniques, strategies and methods of Descriptive survey type research to collect, analyze and interpret the data in the present study.

Population of the Study: There are 404 B.Ed. colleges/institutions (Except Government Colleges and University B.Ed. Departments) among which 32 Government Aided colleges and rest 372 Private colleges are engaged to offer/provide B.Ed. degrees to the trainee teachers or student teachers in the state of West Bengal. Near about 5,500 Teacher Educators are engaged to teach the trainee teachers in those teacher training institutions throughout the state. So, all the Teacher Educators working in those Government Aided and Private B.Ed. colleges/institutions situated in the state of West Bengal have been treated as population for the present study in case of measuring Job Satisfaction.

Sample of the Study: The researcher has selected only 405 Teacher Educators out of which 105 Teacher Educators have been taken from 20 Government Aided B.Ed. colleges and rest 300 Teacher Educators have been taken from 40 Private B.Ed. colleges as a sample for the present study.

Sampling Technique: The Stratified Random sampling technique has been used in the selection of the sample for the present study. At first the researcher has selected two categories of B.Ed. colleges i.e. Government Aided B.Ed. colleges and Private B.Ed. colleges for the present study. Then the researcher has selected 20 Government 
Aided B.Ed. colleges and 40 Private B.Ed. colleges under the affiliation of 8 (Eight) Universities i.e. University of Calcutta, the West Bengal State University (Barasat), University of Kalyani, University of Burdwan, Vidyasagar University, Sidho-Kanho-Birsha University, University of Gour Banga and University of North Bengal in the state of West Bengal purposively. After that the researcher has selected 405 Teacher Educators out of which 100 Teacher Educators have been taken from 20 Government Aided B.Ed. colleges and rest 300 Teacher Educators have been taken from 40 Private B.Ed. colleges randomly as a sample for the present study.

Tool of the Study: The investigators have used a self made Job Satisfaction Scale as a tool for collecting the data in the present study. The Scale consists of 75 items with the combination of positive (48) and negative (27) items. The Scale has been constructed on the basis of 12 (Twelve) important dimensions, namely- Working Environment, Availability of Infrastructural Facilities, Colleagues Support, Rapport with Students, Recognition by Others, Leadership Qualities of the Principal/Head, Nature of Job, Individual Autonomy, Academic Planning, Policies of College Authority and Management, Salary \& Compensation, and Opportunities for Development. The Scale has been constructed followed by Likert's five point scale i.e. Strongly Agree (S.A), Agree (A), Neutral (N), Disagree (D) and Strongly Disagree (S.D). In this present study, the reliability of the tool has been estimated by calculating Cronbach's alpha $(\alpha)$. The value of Cronbach's alpha $(\alpha)$ is 0.95 which indicates highly reliable internal consistency of the scale.

Techniques of Data Analysis: The present investigators have used Mean, S.D. t-Test, ANOVA and Graph for analyzing the data.

Data Collection Procedure and Scoring: After finally developed the Job Satisfaction Scale, it was administered upon the 405 Teacher Educators of 20 (Twenty) Govt. Aided and 40 (Forty) Private B.Ed. Colleges. In this connection, it is notable to mention that the Job Satisfaction Scale was administered only upon the two categories of Teacher Educators i.e. Full Time Permanent Teachers, and Full Time Teachers. For the purpose of administration of the scale, the authorities (Principals/TICs) of the concerned Colleges and Teacher Educators also were informed well in advance by the investigator with the telephonic conversation to collect data from the Teacher Educators. After getting the permission from the concerned college authority, the investigators met with the Teacher Educators in their leisure hours and distributed the scale or questionnaires among them and clearly explained the necessary instructions regarding what to do and how to rating the items of the scale or questionnaire. There was no time limit to rate the items of the scale or questionnaire. The Teacher Educators were instructed to rate the all items of the scale sincerely and carefully to know the original status of Job Satisfaction of them. After completion of the rating by all the Teacher Educators, the filled in copies of the scale or questionnaire were collected from all of them carefully. Finally, all the Teacher Educators and authority of the college were thanked by the researcher for their heartiest cooperation they extended for the purpose of the study. After collecting the all Questionnaires (405) from the 20 (Twenty) Govt. Aided and 40 (Forty) Private B.Ed. Colleges, the investigator calculated the total score on a Questionnaire by computing the score against the each and every item. In computing the score of each items of the Questionnaire, the investigator has used a preselected method. In case of positive item, direct scoring method that was 5-4-3-2-1 has been used and in case of negative items, reverse scoring method that was 1-2-3-4-5 has been used by the investigator in computing the score of each and every items of the Questionnaire. This total process of computing of the Questionnaire has been done by the investigator very carefully and sensitively.

Techniques of Measuring the Level of Job Satisfaction of Teacher Educators:

Table No-1: Shows the Criteria for measuring the Level of Job Satisfaction of B.Ed. College Teacher Educators

\begin{tabular}{|c|c|c|c|}
\hline Dimensions of Job Satisfaction & \multicolumn{3}{|c|}{$\begin{array}{c}\text { Criteria/Scores for Considering the Level of Job } \\
\text { Satisfaction }\end{array}$} \\
\cline { 2 - 4 } & Respective Neutral Points & Satisfied & Dissatisfied \\
\hline Working Environment & 18 & $>18$ & $<18$ \\
\hline $\begin{array}{c}\text { Availability of } \\
\text { Infrastructural Facilities }\end{array}$ & 24 & $>24$ & $<24$ \\
\hline Colleagues Support & 18 & $>18$ & $<18$ \\
\hline Rapport with Students & 18 & $>18$ & $<18$ \\
\hline Recognition by Others & 15 & $>15$ & $<15$ \\
\hline
\end{tabular}


Job Satisfaction of Teacher Educators in Different Types of B.Ed. Colleges in West Bengal

\begin{tabular}{|c|c|c|c|}
\hline $\begin{array}{c}\text { Leadership Qualities of the } \\
\text { Principal/Head }\end{array}$ & 21 & $>21$ & $<21$ \\
\hline Nature of Job & 27 & $>27$ & $<27$ \\
\hline Individual Autonomy & 15 & $>15$ & $<15$ \\
\hline Academic Planning & 18 & $>21$ & $<21$ \\
\hline $\begin{array}{c}\text { Policies of College Authority } \\
\text { and Management }\end{array}$ & 21 & $>15$ & $<15$ \\
\hline $\begin{array}{c}\text { Salary and Compensation } \\
\text { Opportunities for Development }\end{array}$ & 15 & $>15$ & $<15$ \\
\hline Overall Job Satisfaction & 225 & $>225$ & $<225$ \\
\hline
\end{tabular}

\section{RESULTS AND INTERPRETATION}

$\boldsymbol{H O}_{1:}$ There would not have high level of Job Satisfaction of Teacher Educators working in different types of B.Ed. colleges in West Bengal.

Table No-2: Shows the Number of Items, their respective Neutral Points, Means, and $\mathrm{SD}_{\mathrm{S}}$ of the Entire Group of Teacher Educators on different Dimensions of Job Satisfaction and Overall Job Satisfaction and the Results of ' $t$ '-Test

\begin{tabular}{|c|c|c|c|c|c|c|}
\hline $\begin{array}{l}\text { SL. } \\
\text { No }\end{array}$ & $\begin{array}{c}\text { Dimensions of } \\
\text { Job Satisfaction }\end{array}$ & $\begin{array}{l}\text { Number } \\
\text { of Items }\end{array}$ & $\begin{array}{c}\text { Neutral } \\
\text { Point }\end{array}$ & Mean & S.D & $\begin{array}{c}\text { t-value } \\
(\mathrm{df}=403)\end{array}$ \\
\hline 1 & Working Environment & 6 & 18 & 23.58 & 3.97 & $28.24 * *$ \\
\hline 2 & $\begin{array}{c}\text { Availability of } \\
\text { Infrastructural Facilities }\end{array}$ & 8 & 24 & 27.28 & 6.63 & $9.95 * *$ \\
\hline 3 & Colleagues Support & 6 & 18 & 23.72 & 3.90 & $29.50 * *$ \\
\hline 4 & Rapport with Students & 6 & 18 & 24.73 & 3.19 & $42.46 * *$ \\
\hline 5 & Recognition by Others & 5 & 15 & 20.21 & 3.11 & 33.69** \\
\hline 6 & $\begin{array}{c}\text { Leadership Qualities of the } \\
\text { Principal/Head }\end{array}$ & 7 & 21 & 26.08 & 5.01 & $20.41 * *$ \\
\hline 7 & Nature of Job & 9 & 27 & 29.65 & 5.50 & $9.70 * *$ \\
\hline 8 & Individual Autonomy & 5 & 15 & 18.65 & 3.09 & 23.73** \\
\hline 9 & Academic Planning & 6 & 18 & 22.66 & 3.98 & $23.56 * *$ \\
\hline 10 & $\begin{array}{c}\text { Policies of College Authority } \\
\text { and Management }\end{array}$ & 7 & 21 & 24.68 & 4.86 & $15.24 * *$ \\
\hline 11 & Salary and Compensation & 5 & 15 & 14.74 & 4.42 & 1.18@ \\
\hline 12 & Opportunities for Development & 5 & 15 & 16.95 & 4.30 & $9.11 * *$ \\
\hline 13 & Overall Job Satisfaction & 75 & 225 & 272.93 & 35.13 & $27.46 * *$ \\
\hline
\end{tabular}

*Significant at 0.05, ** Significant at 0.01 and @ Not Significant [Table Value of ' $t$ ' against df $=403$ at 0.05 level $=1.97 \&$ at 0.01 level $=2.59]$.

To examine the level of Job Satisfaction of Teacher Educators working in different types of B.Ed. colleges in West Bengal, the present researcher compared the actual obtained Mean Scores and $\mathrm{SD}_{\mathrm{S}}$ with the Neutral Points or values where it is considered that the value of $\mathrm{SD}_{\mathrm{S}}=0$ of the respective dimensions of Job Satisfaction and Overall Job Satisfaction. And to compare the actual obtained Mean Scores and $\mathrm{SD}_{\mathrm{S}}$ with the Neutral Points or values (with $\mathrm{SD}=0$ ), ' $\mathrm{t}$ '-test is applied (Showing in the table no-). From this table, it is seen that the obtained ' $t$ 'value (27.46) of the whole group of Teacher Educators in respect to Overall Job Satisfaction is greater than the table value at the both 0.05 and 0.01 level of significance (1.97 at 0.05 and 2.59 at 0.01 level of significance). Therefore, the result is significant and it may be concluded that there would have high level of Job Satisfaction of Teacher Educators working in different types of B.Ed. colleges in West Bengal. Hence, the null hypothesis i.e. "There would not have high level of Job Satisfaction of Teacher Educators working in different types of 
B.Ed. colleges in West Bengal' is rejected in general. Beside this, it is also seen that the obtained ' $t$ '-values of the whole group of Teacher Educators in respect to all the dimensions of Job Satisfaction except only Salary \& Compensation dimension, are greater than the table values at the both 0.05 and 0.01 level of significance.

Further, it is also observed that the obtained Mean Scores of the whole group of Teacher Educators are greater than their respective Neutral Points or values in case of eleven dimensions of Job Satisfaction and Overall Job Satisfaction. In case of only one dimension i.e. Salary \& Compensation, the whole group of Teacher Educators' obtained mean score is lower than the respective neutral point or value but it is not statistically significant. Hence, it may be concluded that the Teacher Educators working in different Govt. Aided and Private B.Ed. colleges in West Bengal are satisfied with their job.

Figure No-2: Shows the Neutral Points and actual Obtained Mean Scores on the different Dimensions of Job Satisfaction of Entire Group of B.Ed. College Teacher Educators

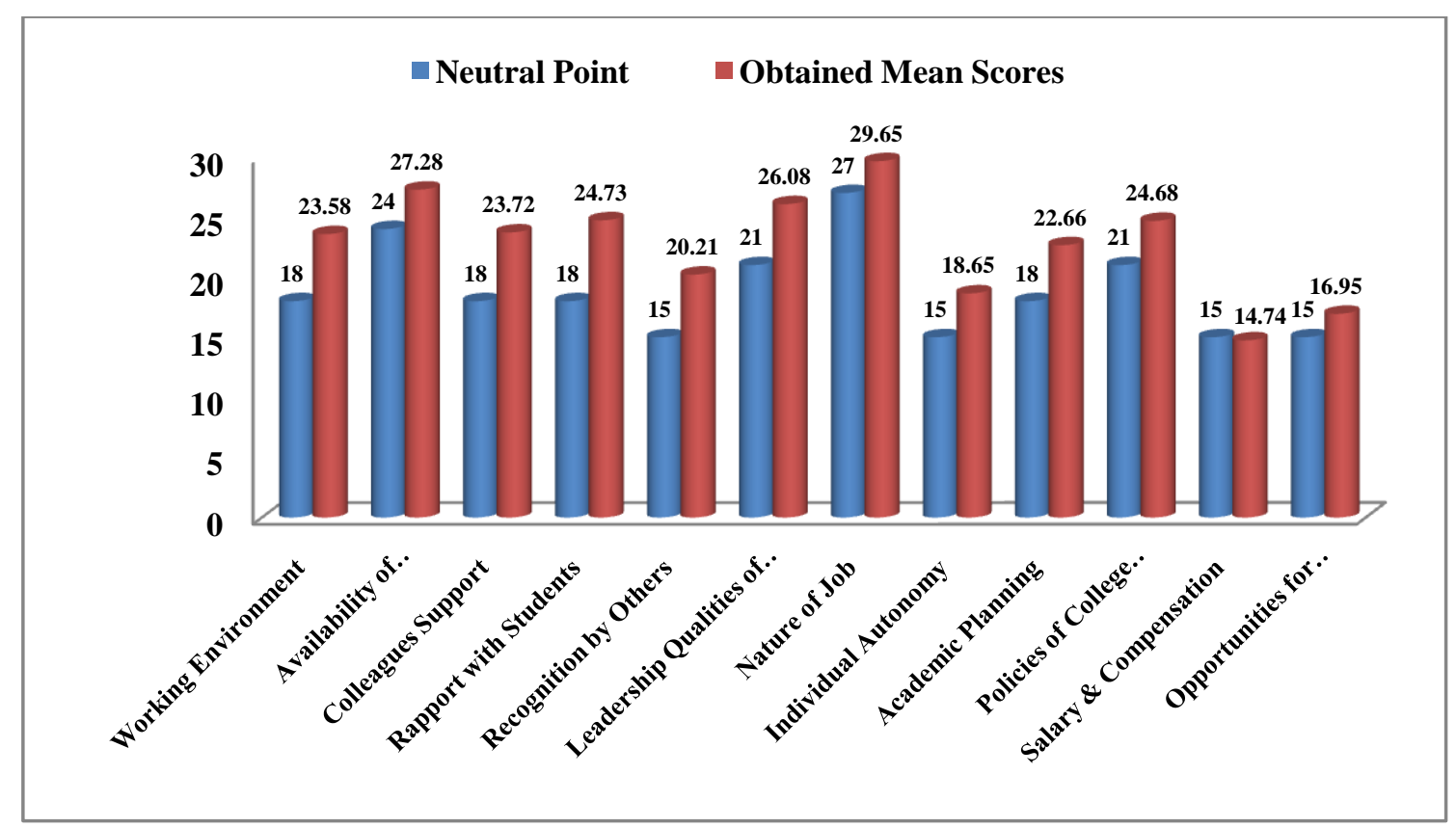

Figure No-3: Shows the Neutral Point and actual Obtained Mean Scores on Overall Job Satisfaction of Entire Group of B.Ed. College Teacher Educators

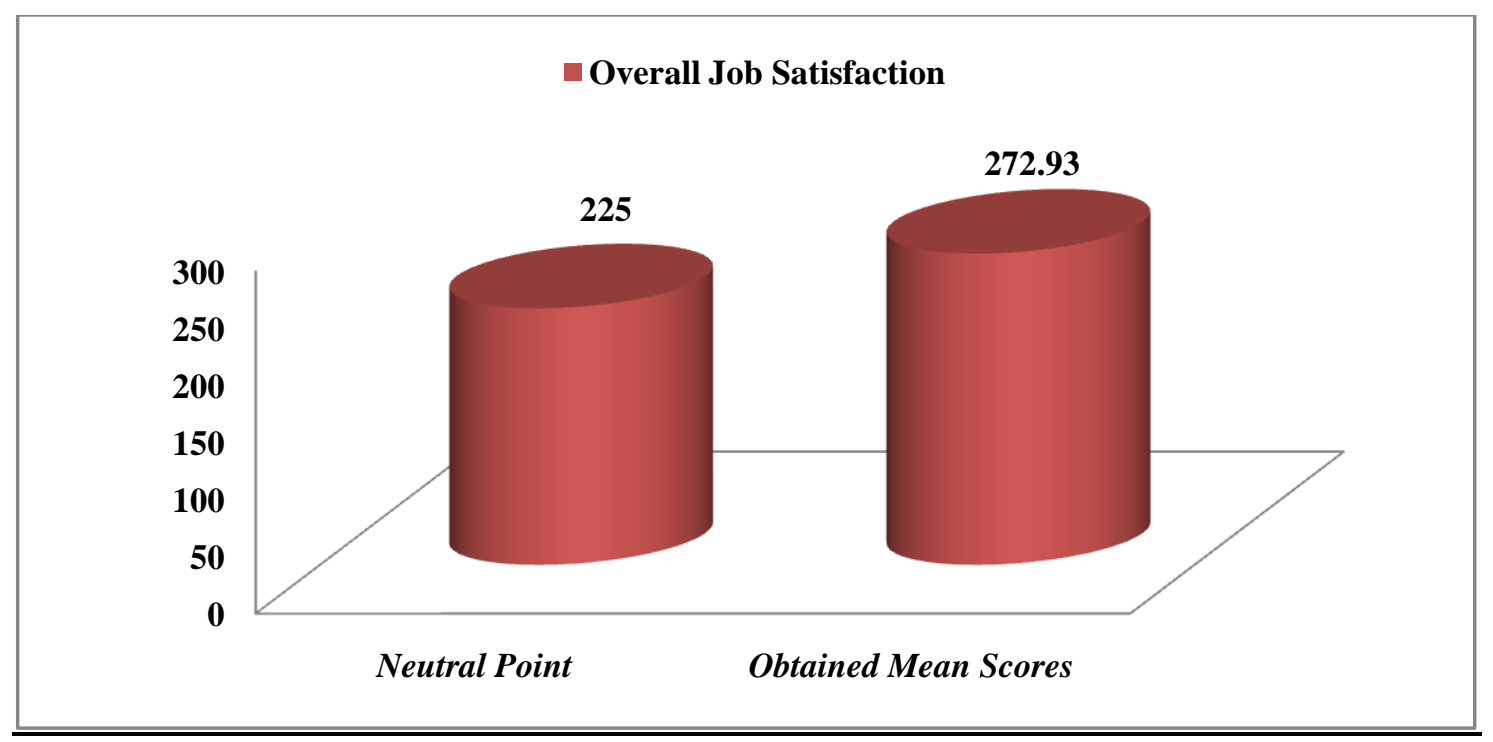

From the table no-, it is also seen that out of total 405 Teacher Educators 371(91.60\%) Teacher Educators fall above the Neutral Point i.e. 225. And only 34 (8.40\%) Teacher Educators fall below the Neutral Point i.e. 225 (Showing in the Fig No-). Therefore, from the observation, it can be inferred that the majority of Teacher 
Educators working in different Govt. Aided and Private B.Ed. colleges in West Bengal are satisfied with their job.

Figure No-4: Histogram shows the Number and Percentages of Satisfied and Dissatisfied B.Ed. College Teacher Educators

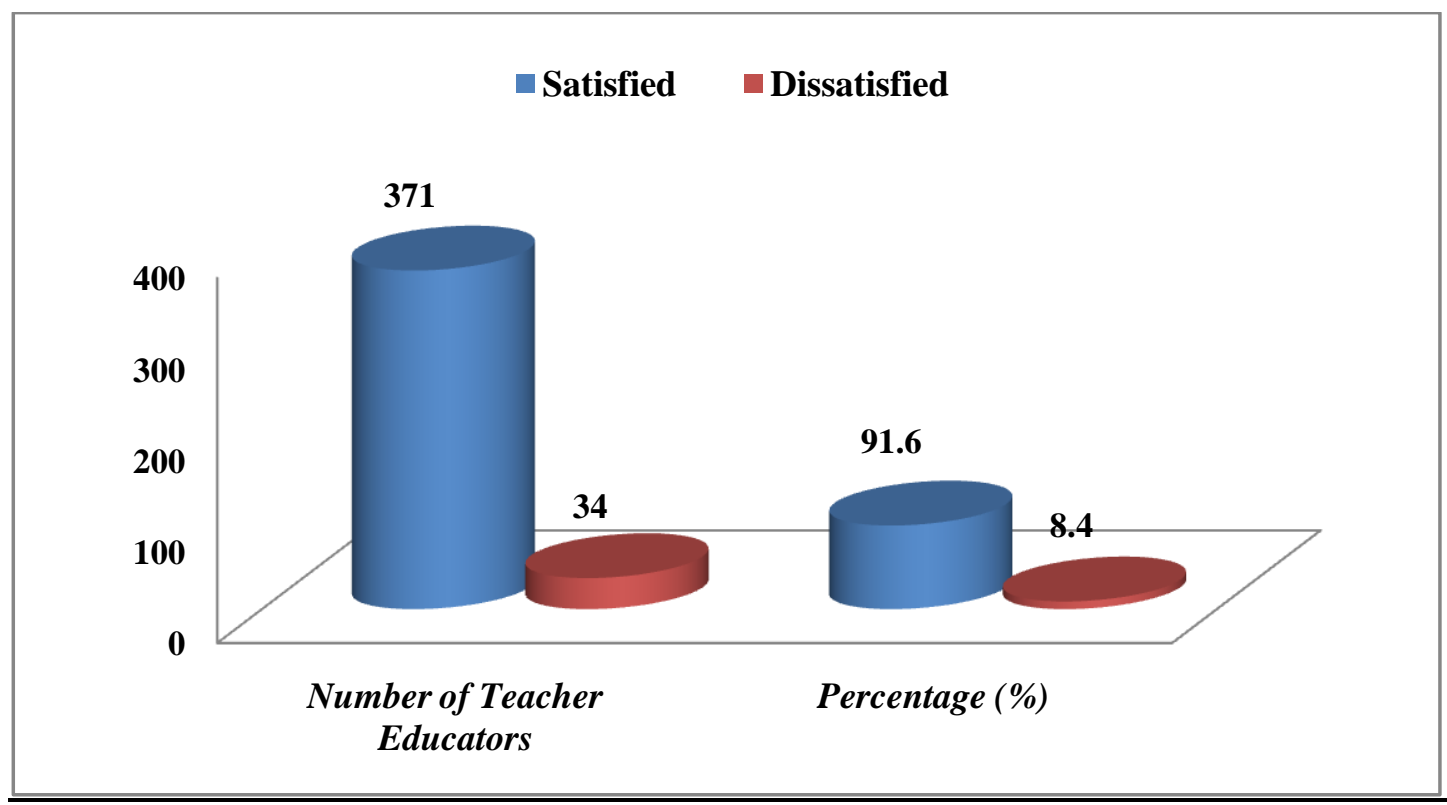

Table No-3: Shows the Influence of Gender, Marital Status, Educational Qualification, Teacher's Locality, Location of College, Type of Family, and Type of Management on Overall Job Satisfaction of B.Ed. College Teacher Educators

\begin{tabular}{|c|c|c|c|c|c|c|c|c|}
\hline Variables & Groups & $\mathbf{N}$ & Mean & SD & df & $\begin{array}{c}\text { Mean } \\
\text { Difference }\end{array}$ & $\mathbf{S}_{\mathrm{ED}}$ & $\begin{array}{c}\text { t- } \\
\text { value }\end{array}$ \\
\hline \multirow[t]{2}{*}{ Gender } & Male & 267 & 275.34 & 34.15 & \multirow{2}{*}{403} & \multirow{2}{*}{7.07} & \multirow{2}{*}{3.67} & \multirow{2}{*}{$1.93 @$} \\
\hline & Female & 138 & 268.26 & 36.62 & & & & \\
\hline \multirow{2}{*}{$\begin{array}{c}\text { Marital } \\
\text { Status }\end{array}$} & Married & 228 & 274.65 & 32.96 & \multirow{2}{*}{403} & \multirow{2}{*}{3.95} & \multirow{2}{*}{3.51} & \multirow{2}{*}{ 1.12@ } \\
\hline & Unmarried & 177 & 270.70 & 37.71 & & & & \\
\hline \multirow[t]{2}{*}{$\begin{array}{l}\text { Educational } \\
\text { Qualification }\end{array}$} & $\begin{array}{l}\text { Highly } \\
\text { Qualified }\end{array}$ & 90 & 271.39 & 33.09 & \multirow{2}{*}{403} & \multirow{2}{*}{1.97} & \multirow{2}{*}{4.20} & \multirow{2}{*}{$0.47 @$} \\
\hline & $\begin{array}{l}\text { Suitably } \\
\text { Qualified }\end{array}$ & 315 & 273.37 & 35.72 & & & & \\
\hline \multirow{2}{*}{$\begin{array}{l}\text { Teacher's } \\
\text { Locality }\end{array}$} & Urban & 248 & 274.75 & 33.64 & \multirow{2}{*}{403} & \multirow{2}{*}{4.69} & \multirow{2}{*}{3.58} & \multirow{2}{*}{ 1.31@ } \\
\hline & Rural & 157 & 270.05 & 37.28 & & & & \\
\hline \multirow{2}{*}{$\begin{array}{l}\text { Location of } \\
\text { College }\end{array}$} & Urban & 198 & 278.31 & 33.15 & \multirow{2}{*}{403} & \multirow{2}{*}{10.54} & \multirow{2}{*}{3.45} & \multirow{2}{*}{$3.05 * *$} \\
\hline & Rural & 207 & 267.77 & 36.25 & & & & \\
\hline \multirow{2}{*}{$\begin{array}{l}\text { Type of } \\
\text { Family }\end{array}$} & Joint Family & 155 & 276.14 & 31.91 & \multirow[b]{2}{*}{403} & \multirow[b]{2}{*}{5.19} & \multirow[b]{2}{*}{3.58} & \multirow[b]{2}{*}{ 1.45@ } \\
\hline & $\begin{array}{l}\text { Nuclear } \\
\text { Family }\end{array}$ & 250 & 270.94 & 36.90 & & & & \\
\hline \multirow{2}{*}{$\begin{array}{c}\text { Type of } \\
\text { Management }\end{array}$} & Govt. Aided & 105 & 271.43 & 35.69 & \multirow{2}{*}{403} & \multirow{2}{*}{2.02} & \multirow{2}{*}{3.98} & \multirow{2}{*}{$0.51 @$} \\
\hline & Private & 300 & 273.45 & 34.97 & & & & \\
\hline
\end{tabular}

*Significant at 0.05, ** Significant at 0.01 and @ Not Significant [Table Value of ' $t$ ' against df $=403$ at 0.05 level $=1.97 \&$ at 0.01 level $=2.59]$.

Table No-4: Shows the Number, Means and $\mathrm{SD}_{\mathrm{S}}$ of B.Ed. College Teacher Educators on Overall Job Satisfaction on the basis of their Age, Teaching Experience, Occupation of Spouse, Size of the Family and Monthly Income 
Job Satisfaction of Teacher Educators in Different Types of B.Ed. Colleges in West Bengal

\begin{tabular}{|c|c|c|c|c|}
\hline Variables & Groups & $\mathbf{N}$ & MEAN & S.D \\
\hline \multirow[t]{3}{*}{ Age } & Young & 200 & 271.48 & 37.10 \\
\hline & Middle Aged & 142 & 273.96 & 34.00 \\
\hline & Old Aged & 63 & 275.19 & 31.27 \\
\hline \multirow{3}{*}{$\begin{array}{c}\text { Teaching } \\
\text { Experience }\end{array}$} & 5 or below 5 Years & 246 & 273.49 & 35.79 \\
\hline & Between 6 to 10 Years & 94 & 269.82 & 34.78 \\
\hline & Above 10 Years & 65 & 275.29 & 33.24 \\
\hline \multirow{3}{*}{$\begin{array}{l}\text { Occupation of } \\
\text { Spouse }\end{array}$} & Household & 57 & 275.96 & 35.68 \\
\hline & Employee & 122 & 280.50 & 31.94 \\
\hline & Business & 49 & 258.57 & 26.99 \\
\hline \multirow[t]{3}{*}{ Size of the Family } & Small Family & 227 & 270.81 & 37.63 \\
\hline & Medium Family & $` 118$ & 277.06 & 32.54 \\
\hline & Large Family & 60 & 272.80 & 29.51 \\
\hline \multirow[t]{3}{*}{ Monthly Income } & Low Income Group & 122 & 268.70 & 37.83 \\
\hline & Middle Income Group & 215 & 276.53 & 34.14 \\
\hline & High Income Group & 68 & 269.13 & 32.31 \\
\hline
\end{tabular}

Table No-5: Shows the results of ANOVA on Overall Job Satisfaction Scores of B.Ed. College Teacher Educators on the basis of their Age, Teaching Experience, Occupation of Spouse, Size of the Family and Monthly Income

\begin{tabular}{|c|c|c|c|c|c|}
\hline \multirow[t]{2}{*}{ Variables } & \multicolumn{2}{|c|}{ Sum of Squares } & \multicolumn{2}{|c|}{ Mean Square } & \multirow{2}{*}{$\begin{array}{c}\text { F-value } \\
(\mathrm{df}=2 / 402) \\
\text { and } \\
(\mathrm{df}=2 / 225)\end{array}$} \\
\hline & $\begin{array}{l}\text { Between } \\
\text { Groups }\end{array}$ & $\begin{array}{l}\text { Within } \\
\text { Groups }\end{array}$ & $\begin{array}{c}\text { Between } \\
\text { Groups }\end{array}$ & $\begin{array}{l}\text { Within } \\
\text { Groups }\end{array}$ & \\
\hline Age & 897.365 & 497652.413 & 448.682 & 1237.941 & $0.362 @$ \\
\hline $\begin{array}{c}\text { Teaching } \\
\text { Experience }\end{array}$ & 1348.943 & 497200.835 & 674.471 & 1236.818 & 0.545@ \\
\hline $\begin{array}{c}\text { Occupation of } \\
\text { Spouse }\end{array}$ & 16941.197 & 229724.430 & 8470.599 & 1020.997 & 8.296 *** \\
\hline Size of the Family & 3032.738 & 495517.039 & 1516.369 & 1232.629 & $1.230 @$ \\
\hline Monthly Income & 5946.581 & 492603.197 & 2973.290 & 1225.381 & 2.426@ \\
\hline
\end{tabular}

*Significant at 0.05, ** Significant at 0.01 and @ Not Significant [Table Value of ' $F$ ' against df=2/402 at 0.05 level $=3.02 \&$ at 0.01 level $=4.66$ and $d f=2 / 225$ at 0.05 level $=3.04 \&$ at 0.01 level $=4.71]$.

Testing of $\mathrm{HO}_{2}$ and Interpretation:

From the table no-3, it is observed that the obtained ' $t$ '-value (1.93) with respect to Overall Job Satisfaction of Male and Female Teacher Educators is less than the table value at 0.05 level of significance (1.97 at 0.05 level of significance). Therefore, the result is not significant and it may be concluded that there would not have any significant influence of Gender on Job Satisfaction of Teacher Educators working in different types of B.Ed. colleges in West Bengal. Hence, the null hypothesis i.e. "There would not have any significant influence of Gender on Job Satisfaction of Teacher Educators working in different types of B.Ed. colleges in West Bengal" is accepted in general. Further, it is also observed that the Mean Score (275.34) of Male Teacher Educators is greater than that (268.26) of the Female Teacher Educators. Hence, on the basis of obtained Mean Scores it may be concluded that the Male Teacher Educators have comparatively high level of Job Satisfaction compared to the Female Teacher Educators although it is not statistically significant.

\section{Testing of $\mathrm{HO}_{3}$ and Interpretation:}

From the table no-3, it is observed that the obtained ' $t$ '-value (1.12) with respect to Overall Job Satisfaction of Married and Unmarried Teacher Educators is less than the table value at 0.05 level of significance (1.97 at 0.05 level of significance). Therefore, the result is not significant and it may be concluded that there would not have any significant influence of Marital Status on Job Satisfaction of Teacher Educators working in different types of B.Ed. colleges in West Bengal. Hence, the null hypothesis i.e. "There would not have any significant influence of Marital Status on Job Satisfaction of Teacher Educators working in different types of B.Ed. colleges in West Bengal" is accepted in general. Further, it is also observed that the Mean Score (274.65) of Married Teacher Educators is greater than that (270.70) of the Unmarried Teacher Educators. 
Hence, on the basis of obtained Mean Scores it may be concluded that the Married Teacher Educators have comparatively high level of Job Satisfaction compared to the Unmarried Teacher Educators although it is not statistically significant.

\section{Testing of $\mathrm{HO}_{4}$ and Interpretation:}

From the table no-3, it is observed that the obtained ' $t$ '-value (0.47) with respect to Overall Job Satisfaction of Highly Qualified and Suitably Qualified Teacher Educators is less than the table value at 0.05 level of significance (1.97 at 0.05 level of significance). Therefore, the result is not significant and it may be concluded that there would not have any significant influence of Educational Qualification on Job Satisfaction of Teacher Educators working in different types of B.Ed. colleges in West Bengal. Hence, the null hypothesis i.e. "There would not have any significant influence of Educational Qualification on Job Satisfaction of Teacher Educators working in different types of B.Ed. colleges in West Bengal" is accepted in general. Further, it is also observed that the Mean Score (271.39) of Highly Qualified Teacher Educators is lower than that (273.37) of the Suitably Qualified Teacher Educators in respect to their Overall Job Satisfaction. Hence, on the basis of obtained Mean Scores it may be concluded that the Highly Qualified Teacher Educators have comparatively low level of Job Satisfaction compared to the Suitably Qualified Teacher Educators although it is not statistically significant.

\section{Testing of $\mathrm{HO}_{5}$ and Interpretation:}

From the table no-3, it is observed that the obtained ' $t$ '-value (1.31) with respect to Overall Job Satisfaction of Urban and Rural Locality Teacher Educators is less than the table value at 0.05 level of significance (1.97 at 0.05 level of significance). Therefore, the result is not significant and it may be concluded that there would not have any significant influence of Teacher's Locality on Job Satisfaction of Teacher Educators working in different types of B.Ed. colleges in West Bengal. Hence, the null hypothesis i.e. "There would not have any significant influence of Teacher's Locality on Job Satisfaction of Teacher Educators working in different types of B.Ed. colleges in West Bengal"' is accepted in general. Further, it is also observed that the Mean Score (274.75) of Urban Locality Teacher Educators is greater than that (270.05) of the Rural Locality Teacher Educators in respect to their Overall Job Satisfaction. Hence, on the basis of obtained Mean Scores it may be concluded that the Urban Locality Teacher Educators have comparatively high level of Job Satisfaction compared to the Rural Locality Teacher Educators although it is not statistically significant.

\section{Testing of $\mathrm{HO}_{6}$ and Interpretation:}

From the table no-3, it is observed that the obtained ' $t$ '-value (3.05) with respect to Overall Job Satisfaction of Urban and Rural College Teacher Educators is greater than the table value at the both 0.05 and 0.01 level of significance (1.97 at 0.05 and 2.59 at 0.01 level of significance). Therefore, the result is significant and it may be concluded that there would have significant influence of Location of College on Job Satisfaction of Teacher Educators working in different types of B.Ed. colleges in West Bengal. Hence, the null hypothesis i.e. "There would not have any significant influence of Location of College on Job Satisfaction of Teacher Educators working in different types of B.Ed. colleges in West Bengal" is rejected in general. Further, it is also observed that the Mean Score (278.31) of Urban College Teacher Educators is greater than that (267.77) of the Rural College Teacher Educators in respect to their Overall Job Satisfaction. Hence, on the basis of obtained Mean Scores it may be concluded that the Urban College Teacher Educators have comparatively high level of Job Satisfaction compared to the Rural College Teacher Educators and it is statistically significant.

\section{Testing of $\mathrm{HO}_{7}$ and Interpretation:}

From the table no-3, it is observed that the obtained ' $t$ '-value (1.45) with respect to Overall Job Satisfaction of Teacher Educators belongs to Joint and Nuclear Family, is less than the table value at 0.05 level of significance (1.97 at 0.05 level of significance). Therefore, the result is not significant and it may be concluded that there would not have any significant influence of Type of Family on Job Satisfaction of Teacher Educators working in different types of B.Ed. colleges in West Bengal. Hence, the null hypothesis i.e. "There would not have any significant influence of Type of Family on Job Satisfaction of Teacher Educators working in different types of B.Ed. colleges in West Bengal" is accepted in general. Further, it is also observed that the Mean Score (276.14) of Teacher Educators belongs to Joint Family is greater than that (270.94) of the Teacher Educators who belongs to Nuclear Family in respect to their Overall Job Satisfaction. Hence, on the basis of obtained Mean Scores it may be concluded that the Teacher Educators belongs to Joint Family have comparatively high level of Job Satisfaction compared to the Teacher Educators who belongs to Nuclear Family although it is not statistically significant.

\section{Testing of $\mathrm{HO}_{8}$ and Interpretation:}


From the table no-3, it is observed that the obtained ' $t$ '-value $\mathbf{( 0 . 5 1 )}$ with respect to Overall Job Satisfaction of Teacher Educators working in different Govt. Aided and Private B.Ed. Colleges, is less than the table value at 0.05 level of significance (1.97 at 0.05 level of significance). Therefore, the result is not significant and it may be concluded that there would not have any significant influence of Type of Management of the College/Institution on Job Satisfaction of Teacher Educators working in different types of B.Ed. colleges in West Bengal. Hence, the null hypothesis i.e. "There would not have any significant influence of Type of Management of the College/Institution on Job Satisfaction of Teacher Educators working in different types of B.Ed. colleges in West Bengal"' is accepted in general. Further, it is also observed that the Mean Score (271.43) of Govt. Aided B.Ed. College Teacher Educators is lower than that (273.45) of the Teacher Educators who are working in different Private B.Ed. Colleges in respect to their Overall Job Satisfaction. Hence, on the basis of obtained Mean Scores it may be concluded that the Govt. Aided B.Ed. College Teacher Educators are comparatively less satisfied with their job as compared to the Teacher Educators who are working in different Private B.Ed. Colleges in West Bengal although it is not statistically significant.

\section{Testing of $\mathrm{HO}_{9}$ and Interpretation:}

From the table no-5, it may be seen that the obtained 'F'-value (0.362) with respect to Overall Job Satisfaction of the three different Aged groups of Teacher Educators, is less than the table value at 0.05 level of significance. Therefore, the result is not significant and it may be concluded that there would not have any significant influence of Age on Job Satisfaction of Teacher Educators working in different types of B.Ed. colleges in West Bengal. Hence, the null hypothesis i.e. "There would not have any significant influence of Age on Job Satisfaction of Teacher Educators working in different types of B.Ed. colleges in West Bengal” is accepted in general. But on the basis of obtained Mean Scores, it is observed that the Old Aged group of Teacher Educators is comparatively more satisfied with their job than the other two groups of Teacher Educators but it is not statistically significant.

\section{Testing of $\mathrm{HO}_{10}$ and Interpretation:}

From the table no-5, it may be seen that the obtained 'F'-value (0.545) with respect to Overall Job Satisfaction of the three different Experienced groups of Teacher Educators, is less than the table value at 0.05 level of significance. Therefore, the result is not significant and it may be concluded that there would not have any significant influence of Teaching Experience on Job Satisfaction of Teacher Educators working in different types of B.Ed. colleges in West Bengal. Hence, the null hypothesis i.e. "There would not have any significant influence of Teaching Experience on Job Satisfaction of Teacher Educators working in different types of B.Ed. colleges in West Bengal" is accepted in general. But on the basis of obtained Mean Scores, it is observed that the High Experienced group of Teacher Educators is comparatively more satisfied with their job than the other two groups of Teacher Educators but it is not statistically significant.

\section{Testing of $\mathrm{HO}_{11}$ and Interpretation:}

From the table no-5, it may be seen that the obtained 'F'-value (8.296) with respect to Overall Job Satisfaction of these three different groups of Teacher Educators, is greater than the table value at the both 0.05 and 0.01 level of significance. Therefore, the result is significant and it may be concluded that there would have a significant influence of Occupation of Spouse on Job Satisfaction of Teacher Educators working in different types of B.Ed. colleges in West Bengal. Hence, the null hypothesis i.e. "There would not have any significant influence of Occupation of Spouse on Job Satisfaction of Teacher Educators working in different types of B.Ed. colleges in West Bengal" is rejected in general. On the basis of obtained Mean Scores, it is observed that the Teacher Educators having employee spouse are comparatively more satisfied with their job than the Teacher Educators having household and business spouse.

\section{Testing of $\mathrm{HO}_{12}$ and Interpretation:}

From the table no-5, it may be seen that the obtained 'F'-value (1.230) with respect to Overall Job Satisfaction of these three different groups of Teacher Educators, is less than the table value at 0.05 level of significance. Therefore, the result is not significant and it may be concluded that there would not have any significant influence of Size of the Family on Job Satisfaction of Teacher Educators working in different types of B.Ed. colleges in West Bengal. Hence, the null hypothesis i.e. "There would not have any significant influence of Size of the Family on Job Satisfaction of Teacher Educators working in different types of B.Ed. colleges in West Bengal" is accepted in general. But on the basis of obtained Mean Scores, it is observed that the Teacher Educators having with Medium Family are comparatively more satisfied with their job than the other two groups of Teacher Educators but it is not statistically significant.

\section{Testing of $\mathrm{HO}_{13}$ and Interpretation:}


From the table no-5, it may be seen that the obtained "F'-value (2.426) with respect to Overall Job Satisfaction of these three different income groups of Teacher Educators, is less than the table value at 0.05 level of significance. Therefore, the result is not significant and it may be concluded that there would not have any significant influence of Monthly Income on Job Satisfaction of Teacher Educators working in different types of B.Ed. colleges in West Bengal. Hence, the null hypothesis i.e. "There would not have any significant influence of Monthly Income on Job Satisfaction of Teacher Educators working in different types of B.Ed. colleges in West Bengal" is accepted in general. But on the basis of obtained Mean Scores, it is observed that the Middle Income group of Teacher Educators is comparatively more satisfied with their job than the other two income groups of Teacher Educators. And the Low Income group of Teacher Educators is comparatively less satisfied with their job than the other two income groups of Teacher Educators but it is not statistically significant.

\section{MAJOR FINDINGS AND DISCUSSION OF THE RESULTS}

The present study revealed that the Teacher Educators working in different Govt. Aided and Private B.Ed. colleges in West Bengal are satisfied with their job overall. The similar finding is also reported by Goyal (1980); Kishore (2006); Srivastava \& Chabra (2012); Prajapati \& Mohalik (2013); Chandramma (2013); Alemi (2014); and Bordhan (2015). But this finding of the present study contradicts the study conducted by Gangadhar Rao (2012). He reported that the In-Service M.Ed. Teacher Trainees working at teacher training institutions were not satisfied in their job. Beside this, it is also revealed through the present study that the Teacher Educators are not satisfied with their salary and compensation aspect of their job which they are getting from their job. This finding of the present study is in line with the study conducted by Balwaria (2013). He reported that secondary Teacher Educators of Gujarat were not satisfied with the poor pay scale that they were enjoying from their job.It is found through the present study that Gender has no statistically significant influence on overall Job Satisfaction of Teacher Educators working in different types of B.Ed. colleges in West Bengal. This finding of the present study is supported by Goyal (1985); Kishore (2006); Sylvester (2010); Sridevi (2011); Bhayana (2012); Singh (2012); Srivastava \& Chabra (2012); Chandramma (2013); Anees (2013); Alemi (2014); and Thakur (2014). But it contradicts the findings of the studies conducted by Biswas (1994); Gangadhar Rao (2012); Prajapati \& Mohalik (2013); Bordhan (2015); and Oladosu Christianah Tinu et al., (2015). They showed that there was a significant difference in Job Satisfaction between male and female Teacher Educators. The present study revealed that Marital Status has no statistically significant influence on overall Job Satisfaction of Teacher Educators working in different types of B.Ed. colleges in West Bengal. This finding of the present study is not in line with the studies conducted by Chandramma (2013); and Alemi (2014). They showed that marital status has a significant effect or influence on Job Satisfaction of Teacher Educators. They reported that the unmarried Teacher Educators expressed higher level of Job Satisfaction than their married counterparts. Through the present study it is found that Educational Qualification has no statistically significant influence on overall Job Satisfaction of Teacher Educators working in different types of B.Ed. colleges in West Bengal. This finding of the present study is supported by Balwaria (2013). But it is not in line with the studies conducted by Srivastava \& Chabra (2012); Prajapati \& Mohalik (2013); and Bordhan (2015). They reported that Educational Qualification had a statistically significant influence on overall Job Satisfaction of Teacher Educators. Through the present study it is found that Teacher's Locality has no statistically significant influence on overall Job Satisfaction of Teacher Educators working in different types of B.Ed. colleges in West Bengal. This finding of the present study is supported by Biswas (1994); and Singh (2012). But it contradicts the findings of the studies conducted by Rathod \& Verma (2006); Khaleque (2007); Ngimbudzi (2009); Kaur (2010); Kaur \& Sidana (2011); Kaur (2011); and Gupta, Pasrija \& Bansal (2012). They reported that location of the teacher's residence has a significant influence or effect on the level of Job Satisfaction of teachers. The present study revealed that Location of College has a statistically significant influence on overall Job Satisfaction of Teacher Educators working in different types of B.Ed. colleges in West Bengal. This finding of the present study is supported by Alemi (2014); Kaur (2010); Kaur \& Sidana (2011); and Gupta, Pasrija \& Bansal (2012). But it contradicts the findings of the studies conducted by Sylvester (2010); Sridevi (2011) and Chandramma (2013). They reported that location of institutes have no significant impact on the level of Job Satisfaction of Teacher Educators. Through the present study it is found that Type of Family has no statistically significant influence on overall Job Satisfaction of Teacher Educators working in different types of B.Ed. colleges in West Bengal. This finding of the present study is supported by Srenivasan (2007); Tuq (2008); Rajesh (2009); Promod (2010); Chandramma (2013); and Behera (2014). But this finding of the present study contradicts the findings of the studies conducted by Jalaja (2004). She reported that the number of members in the family has a significant influence on overall Job Satisfaction of Teachers.

The present study revealed that Type of Management of the College/Institution has no statistically significant influence on overall Job Satisfaction of Teacher Educators working in different types of B.Ed. 
colleges in West Bengal. This finding of the present study is supported by Panda (2002); Venkateswara Rao (2002); Mary \& Raj (2005); Sharma \& Tyagi (2010); Rajesh Biswal (2010); Akhtar \& Naqvi (2010); Massey (2011); and Anees (2013). But it is not in line with the studies conducted by Nobi, Abdal \& Sajid (2003); Shyam et al. (2004); Sharma \& Kumari (2004); Vijayalakshmi (2005); Ghali (2005); Sharma \& Jyothi (2006); Crossman \& Harris (2006); Thakur (2007); Newa (2007); Kaur \& Kumar (2008); Saveri (2009); Sharma \& Patnaik (2009); Ngimbudzi (2009); Kaur (2010); Gupta (2010); Kaur \& Sidana (2011); Gupta \& Gehlawat (2013); Sarswati (2013); Ohri (2013); Chandramma (2013); and Kataria (2014). They reported that type of management of the institution has a significant influence or effect on the level of Job Satisfaction of teachers. Through the present study it is found that Age has no statistically significant influence on overall Job Satisfaction of Teacher Educators working in different types of B.Ed. colleges in West Bengal. This finding of the present study is supported by Singh (2012). But it contradicts the findings of the studies conducted by Prajapati \& Mohalik (2013); Chandramma (2013); Alemi (2014); and Bordhan (2015). They showed that Age has a statistically significant influence on Job Satisfaction of Teacher Educators. The present study revealed that Teaching Experience has no statistically significant influence on overall Job Satisfaction of Teacher Educators working in different types of B.Ed. colleges in West Bengal. This finding of the present study is supported by Goyal (1985), Sylvester (2010); Bhayana (2012); and Chandramma (2013). But it contradicts the findings of the studies conducted by Prajapati \& Mohalik (2013); Balwaria (2013); Alemi (2014); and Bordhan (2015). Through the present study it is found that Occupation of Spouse has a statistically significant influence on Job Satisfaction of Teacher Educators working in different types of B.Ed. colleges in West Bengal. But this finding of the present study contradicts the findings of the study conducted by Chandramma (2013). She reported that Occupation of Spouse has no statistically significant influence on Job Satisfaction of Teacher Educators. The present study revealed that Size of the Family has no statistically significant influence on overall Job Satisfaction of Teacher Educators working in different types of B.Ed. colleges in West Bengal. This finding of the present study is supported by Srenivasan (2007); Tuq (2008); Rajesh (2009); Promod (2010); Chandramma (2013); and Behera (2014). But this finding of the present study contradicts the findings of the studies conducted by Jalaja (2004); and Katoch (2012).

\section{CONCLUSION}

From the above findings the following conclusions are drawn:

1. Teacher Educators working in different Govt. Aided and Private B.Ed. colleges in West Bengal are satisfied with their job overall. They are satisfied with all the dimensions or aspects of Job Satisfaction except only one dimension i.e. salary \& compensation.

2. Out of 13 personal and socio-demographic variables only two variables viz., (i) Location of College and (ii) Occupation of Spouse have a statistically significant influence on overall Job Satisfaction of Teacher Educators working in different types of B.Ed. colleges in West Bengal.

3. On the other side, Gender, Marital Status, Educational Qualification, Teacher's Locality, Type of Family, Type of Management of the College, Age, Teaching Experience, Size of the Family, and Monthly Income of a Teacher Educator have no statistically significant influence on overall Job Satisfaction of Teacher Educators working in different types of B.Ed. colleges in West Bengal.

4. The Teacher Educators who are working in different B.Ed. colleges situated in urban areas have comparatively high level of Job Satisfaction as compared to the Teacher Educators who are working in rural area's B.Ed. colleges.

5. The Teacher Educators having employee spouse are comparatively more satisfied with their job as compared to the Teacher Educators having household and business spouse. And the Teacher Educators having business spouse are comparatively less satisfied with their job than the Teacher Educators having household and employee spouse.

Therefore, through the present study it is clear that the Teacher Educators working in different types of B.Ed. colleges in West Bengal are satisfied with their job. Beside this, it is also clear that they are not satisfied with their salary and compensation that they are getting from their job. Hence, this issue should have to take into consideration by the concerned authorities and government and have to take few effective measures especially in case of private B.Ed. colleges in order to ensure as well as increase the level of Job Satisfaction of Teacher Educators.

\section{REFERENCES}

[1] Akhtar, S.N., Hashmi, M.A., and Naqvi, S.I.H. (2010). A Comparative Study of Job Satisfaction in Public and Private School Teachers at Secondary Level. Procedia - Social and Behavioral Sciences, 2 (2), 4222 4228. 
[2] Alemi, B. (2014). Job Satisfaction among Afghan Teacher Educators. Teacher Education Master Programme, Unpublished.

[3] Anees, A. (2013). A Comparative study of Job Satisfaction of Teacher Educators working in Public Funded Institutions in Relation to their Work Motivation. Excellence International Journal of Education and Research, 1(3), 250-260.

[4] Anees, A. (2013). A Comparative Study of Job Satisfaction of Teacher Educators Working in Private and Public Funded Institutions in Relation to their Work Motivation And Occupational Aspirations. http://hdl.handle.net/10603/12955.

[5] Balwaria, R. R. (2013). A Study of Job Satisfaction of Teacher Educators Associated With Professional Variable. International Educational E-Journal (Quarterly), 2 (4), 77-96.

[6] Behera, Diptimayee (2014). Job Satisfaction of Mainstream School Teachers in West Bengal. International Journal of Scientific Research, 3 (7), 125-127.

[7] Bhayana, S. (2012). A Study of Occupational Self Efficacy, Job Satisfaction and Attitude towards Teaching Profession among Teachers Working in Teacher Training Institutions. Doctoral Thesis. M.D. University, Rohtak.

[8] Biswas, Chandra (1994). Job Satisfaction and Work Involvement among Teacher Educators of Private and Public Sectors in Orissa. Psychological Studies, 43, 85-89.

[9] Bordhan, S. (2015). Job Satisfaction of Teacher Educators in Relation to Sex, Qualification, Experience and Age at Secondary Level in Kamrup and Nagaon Districts of Assam. International Journal of Multidisciplinary Research and Development, 2 (3), 703-706.

[10] Bretz, R. D., and Thomas, S. L. (1992). Perceived Equity, Motivation, and Final Offer Arbitration in Major League Baseball. Journal of Applied Psychology, 77, 280-287.

[11] Chandramma, M. (2013). Job Satisfaction and Teaching Effectiveness of Teacher Educators. Lambert Academic Publishing.

[12] Crossman, A., and Harris, P. (2006). Job Satisfaction of Secondary School Teachers. Educational Management Administration Leadership, 34 (1), 29-46.

[13] Dhondiram, D. S. (2014). A Study of the Relationship between Job Satisfaction and Teaching Aptitude of Teacher Educators in Colleges of Education. Research Front, 1, 37-40.

[14] Eryaman, Mustafa Yunus \& Sonmezer, Mehmet Gursel (2008). A Comparative Analysis of Job Satisfaction Levels of Public and Private School Teachers. Journal of Theory and Practice in Education Articles/Makaleler, 4 (2), 189-212. http://eku.comu.edu.tr/index/4/2/mgsonmezer_myeryaman.pdf

[15] Gangadhar Rao K. M. (2012). A Comparative Study between Job Satisfaction and Effectiveness in Teaching of In-Service Teacher Trainees. Golden Research Thoughts, 2 (3), 1-4.

[16] Ghali. (2005). Teacher Effectiveness and Job Satisfaction of Women Teachers. Edutrack, 4 (7), 34-40.

[17] Ghosh, T. K., \& Panda, U. K. (2014). A Comparative Study of Job Satisfaction among Teacher Educators in Different Types of Secondary Teachers' Training Institution in West Bengal. Indian Journal of Applied Research, 4 (6), 163-165.

[18] Goyal, J. C. (1985). The Indian Teacher Educator - Some Characteristics, National Psychological Corporation, Agra, Uttar Pradesh, India.

[19] Goyal, M. (1980). A Study of the Relationship among Attitudes of Job Satisfaction, Adjustment and Professional Interest of Teacher Educators in India. Third Survey of Research in Education, 805.

[20] Gupta, M., Pasrija, P., and Bansal, K.K. (2012). Job Satisfaction of Secondary School Teachers in Relation To Some Demographic Variables: A Comparative Study. Journal of Education and Research for Sustainable Development, 1(1), 8-17.

[21] Gupta, M., and Gehlawat, M. (2013). Job Satisfaction and Work Motivation of Secondary School Teachers in Relation to Some Demographic Variables: A Comparative Study. Vidya Shodh: A Bilingual \& Biannual Journal of Education and Allied Humanities, 1 (1), 1-13.

[22] Gupta, S. P. (2010). A Correlational Study of Teachers' Job Satisfaction and their Teaching Effectiveness. The Progress of Education, 69 (10), 207-208.

[23] Harrel, T. W. (1968). A Study of Job Satisfaction and Dissatisfaction among Faculty members in Teacher Training Institutes in Thailand. Dissertation Abstracts International, 42, 468-A.

[24] Herzberg, F. (1968). One More Time: How Do You Motivate Employees? Harvard Business Review, 46 (1), 53-62.

[25] Herzberg, F., Mausner, B., \& Snyderman, B. B. (1959, 1987). The Motivation to Work. New York: John Wiley \& Sons. As quoted in Malik, N. A Study on Job Satisfaction factors of faculty members at the University of Balochistan. Journal of Research in Education, 21 (2), 50.

[26] Ingersoll, R. (2001). Teacher Turnover and Teacher Shortages: An Organizational Analysis. American Educational Research Journal, 38 (3), 499-534. 
[27] Jalaja, S. S. (2004). Bureaucratism of College Teachers and ther Attitude towards Teaching Profession. M.Phil. Dissertation, D.D.E., M.K.University, Madurai.

[28] Kataria, S. (2014). Job Satisfaction among Government and Private School Teachers. Educationia Confab, 3 (6), 6-11.

[29] Katoch, Om Raj (2012). Job Satisfaction among College Teachers: A Study on Government Colleges in Jammu (J\&K). Asian Journal of Research in Social Science \& Humanities, 2 (4), 164-180.

[30] Kaur, G. (2010). Level of Job Satisfaction of College Teachers of Punjab with Respect to Area, Gender and Type of Institution. SAJOSPS, 11 (1), 57-64.

[31] Kaur, G., and Sidana, J. J. (2011). Job Satisfaction of College Teachers of Punjab with Respect to Area, Gender and Type of Institution. Edutracks, 10 (11), 27-35.

[32] Kaur, S. (2011). Job Satisfaction and Occupational Stress among School Teachers: A Correlational Study. International Referred Research Journal, 3 (34), 49-50.

[33] Kaur, S., and Kumar, D. (2008). Comparative Study of Government and Non Government College Teacher in Relation to Job Satisfaction and Job Stress. Unpublished Dissertation.

[34] Khaleque, A. (2007). Teachers of Higher Education and Their Job Satisfaction of Barpeta District in Assam. Recent Researches in Education and Psychology, 12 (3-4), 68-72.

[35] Khan, Afsar (1995). Job Satisfaction-Definitions and Theories. Journal of Indian Education, 21 (1), 23 28.

[36] Khan, M. A., \& Verma, D. K. (2013). Job Satisfaction of Teacher Educators of Private B.Ed. Colleges Affiliated to G.G.S.I.P. University, Delhi and M. D. University, Rohtak, Haryana: A Comparative Study. Anveshanam - The Journal of Education, 2 (1), 23-29.

[37] Kim, I., \& Loadman, W. (1994). Predicting Teacher Job Satisfaction. Columbus, Ohio State University, Peter Lang :New York.

[38] Kishore, T. (2006). Job Satisfaction of Teacher Educators working in B.Ed. Colleges. Ph.D. Thesis, S.V University, Tirupati.

[39] Mary, S. R., and Raj, P. (2005). Job Satisfaction of Government School Teachers in Pondicherry Region. Journal of All India Association for Educational Research. 17 (1-2), 80-81.

[40] Massey, J. P. (2011). A Study of Difference in Intensity of Relationship between Teacher Freezing and Job Satisfaction of Secondary School Teachers. Journal of Educational and Psychological Research, 1 (2), 89-94.

[41] Motowidlo, S. J. (1983). Predating Sales Turnover from Pay Satisfaction and Expectation. Journal of Applied Psychology, 68, 484-489.

[42] Newa, D. R. (2007). Teaching Effectiveness and Job Satisfaction among Government and Private College Teachers of Nepal. Unpublished Doctoral Thesis, Panjab University, Chandigarh.

[43] Ngimbudzi, W. (2009). Job Satisfaction among Secondary School Teachers in Tanzania: A Case Study of Njombe District. Unpublished Master Thesis of Education. Department of Educational Sciences Institute of Educational Leadership University of Jyvaskyla.

[44] Nobi, A., Abdal, R., \& Sajid, J. (2003). Job Satisfaction among School Teachers. The Educational Review, 7.

[45] Ohri, Neetu (2013). A Study of Teacher Effectiveness and Job Satisfaction of Secondary School Teachers. Indian Streams Research Journal, 3 (10), 1-4.

[46] Oladosu Christianah Tinu et al. (2015). Gender Influence on Job Satisfaction and Job Commitment among Colleges of Education Lecturers. Journal of Education and Practice, 6 (13), 159-161.

[47] Panda, M. (2002). A Study of Job Satisfaction of Teachers in the Context of Types of Management. The Educational Review, 45 (4), 16-19.

[48] Prajapati, S., \& Mohalik, R. (2013). Job Satisfaction of Teacher Educators in Relation to Sex, Qualification, Experience and Age at Secondary Level in Bihar. International Educational E-Journal, 2 (3), 106-113.

[49] Prasad, L. M. (2004). (1st ed.). Management Process and Organizational Behaviour. Sultan Chand and Sons, New Delhi.

[50] Promod, V. (2010). Job Satisfaction and Personality of the Technical Teachers. Journal of Education and Extension, 10 (1), 11-13.

[51] Rajesh, A. (2009). Job Satisfaction of Teachers in Tamilnadu. Educational Review, Sarva Siksha Abhiyan, Chennai, T.N. 229.

[52] Rajesh Biswal, D. (2010). Influence of Certain Academic and Administrative Factors on the Job Satisfaction of Higher Secondary School Teachers in Rajasthan. University Journal, Rajasthan University, 4, 8 .

[53] Rathod, M. B., \& Verma, M. (2006). Study of Job Satisfaction of Teachers in Relation to Role Commitment. Meri Journal of Education, 1 (1). 
[54] Sargent, T., \& Hannum, E. (2005). Keeping Teachers Happy: Job Satisfaction among Primary School Teachers in Rural Northwest China. Comparative Education Review, 49 (2), 173-204.

[55] Sarswati (2013). A Study to Measure Job Satisfaction Level amongst Lecturers of Government \& Private Colleges in Delhi. International Journal of Research \& Development in Technology and Management S C I (6), 01 - 1 4. Retrieved from http://Journal.Rtmonline.in.

[56] Saveri (2009). Relationship between Job Satisfaction and Life Satisfaction among B.T. Assistant Teachers. Edutrack., 8 (9), 37-40.

[57] Sharma, B. K., and Patnaik, S. P. (2009). Organizational Health of Elementary School and Job Satisfaction of Teachers. Edutracks, 8 (6), 32-34.

[58] Sharma, P., \& Tyagi, N. (2010). A Comparative Study of Job Satisfaction in Relation to Teacher Effectiveness of Government and Private School Teachers at Secondary Level. New Era College of Science and Technology Journal of Teacher Training, 2 (1), 21-24.

[59] Sharma, R. D., \& Jyothi, J. (2006). Job Satisfaction among School Teachers. IIMB Management Review, 18 (4), 349-361.

[60] Sharma, S. K., \& Kumari, A. (2004). Job Satisfaction of the Employees. Sajosps, 4 (2), 64-67.

[61] Shyam, R., Chaudhary. R., \& Kiran, S. (2004). Burnout and Organizational Role Stress: A Study amongst Health Professionals. Indian Management Studies Journal, 8 (1) 1-10.

[62] Singh, A. K. (2009). Tests, Measurements and Research Methods in Behavioural Sciences. Bharati Bhawan, New Delhi.

[63] Singh, N. (2010). Industrial Psychology, Tata Mc-Graw Hill Publishing Company Ltd., New Delhi.

[64] Singh, Y. G. (2012). Job-Satisfaction of Teacher-Educator Working in Self-Finance Teacher Educational Institution. International Indexed \& Referred Research Journal, 3 (30), 54-55.

[65] Spector, P. E. (1997). Job Satisfaction: Application, Assessment, Cause, and Consequences. Thousand Oaks, CA: Sage Publications, Inc.

[66] Srenivasan, C. (2007). Job Satisfaction of Higher Secondary School Teachers. Journal of Community Guidance and Research, 24 (2), 163-172.

[67] Sridevi, K. V. (2011). Job Satisfaction of Teacher Educators of University of Mysore, Edusearch: Journal of Educational Research, 20 (1), 59-65.

[68] Srivastava, S., \& Chabra, S. (2012). Job Satisfaction among Teacher Educators: Interplay of Gender and Qualification. Researcher, 4 (8), 26-30. Retrieved from http://www.sciencepub.net/researcher.

[69] Sylvester, J. M. (2010) Attitude towards Teaching Profession and Job Satisfaction of Teacher Educators. Edutracks, 9 (8), 36-38.

[70] Thakur, M. (2007). Correlates of Job Satisfaction of Secondary School Principals in Bhavnagar District. Experiments in Education, 13-15.

[71] Thakur, N. (2014). A Comparative Study on Job Satisfaction of Teacher Educators in Relation to Private Teachers' Training Institutions of University of Gour Banga and University of Kalyani. International Journal of Education and Psychological Research (IJEPR), 3 (4), 1-5.

[72] Tuq, Abdul (2008). An Interactional Effect of Job Satisfaction with some Variables. Journal of Educational Abstracts, 5 (2), 8-12.

[73] Venkateswara Rao, K. (2002). Job Satisfaction of Primary School Teachers. Unpublished Ph.D. Thesis, Education, S.V. University, Tirupati.

[74] Vijayalakshmi (2005). Teacher Effectiveness and Job Satisfaction of Women Teachers. Edutracks, 4 (7), 7-9.

[75] Watson, A., Hatton, N., Squires, D., \& Soliman, I. (1991). School Staffing and the Quality of Education: Teaching Adjustment and Satisfaction. Teaching and Teaching Education, 7, 63-77.

[76] Weiner, B. (1980). Human Motivation. New York: Holt, Rinehart and Winston.

[77] Woods, A. M., \& Weasmer, J. (2002). Maintaining Job Satisfaction: Engaging Professionals as Active Participants. The Clearing House, 75 (4), 186-189. 